\title{
Boosting Productivity via Innovation and Adoption of New Technologies: Any Role for Labor Market Institutions?
}

\author{
Stefano Scarpetta and Thierry Tressel* \\ World Bank, Human Development Network, and IMF \\ sscarpetta@,worldbank.org; thierry.tressel@,imf.org \\ Tel +1 202458 1119, Fax +1 2025227247
}

\begin{abstract}
:
This paper presents empirical evidence on the determinants of industry-level multifactor productivity growth. We focus on "traditional factors", including the process of technological catch up, human capital and R\&D as well as institutional factors affecting labor adjustment costs. The analysis is based on harmonized data for 17 manufacturing industries in 18 OECD economies over the past two decades. The disaggregated analysis reveals that the process of technological convergence takes place mainly in low-tech industries, while in hightech industries, country leaders tend to pull ahead of the others. The link between $R \& D$ activity and productivity also depends on technological characteristics of the industries: while there is no evidence of $R \& D$ boosting productivity in low-tech industries, the effect is strong in high-tech industries, but the technology leaders tend to enjoy higher returns on $R \& D$ expenditure compared with followers. There is also evidence in the data that high labor adjustment costs (proxied by the strictness of employment protection legislation) can have a strong negative impact on productivity. In particular, when institutional settings do not allow wages or internal training to offset high hiring and firing costs, the latter reduce incentives for innovation and adoption of new technologies, and lead to lower productivity performance. Albeit drawn from the experience of industrial countries, this result may have relevant implications for many developing economies characterized by low relative wage flexibility and high labor adjustment costs.
\end{abstract}

Key words: productivity, convergence, employment protection, industrial relations, panel data

JEL codes: L51, O33, C23, J32

World Bank Policy Research Working Paper 3273, April 2004

The Policy Research Working Paper Series disseminates the findings of work in progress to encourage the exchange of ideas about development issues. An objective of the series is to get the findings out quickly, even if the presentations are less than fully polished. The papers carry the names of the authors and should be cited accordingly. The findings, interpretations, and conclusions expressed in this paper are entirely those of the authors. They do not necessarily represent the view of the World Bank, its Executive Directors, or the countries they represent. Policy Research Working Papers are available online at http://econ.worldbank.org.

* Corresponding author: Stefano Scarpetta. The authors wish to thank Andrea Bassanini, Carlos Cavalcanti, Jørgen Elmeskov, Mike Feiner, Daniel Lederman, Gilles Saint-Paul and Ignazio Visco, as well as the participants to the 2003 World Bank Economists' Forum for useful comments on a previous draft of the paper. The views expressed in this paper are those of the authors and should not be held to represent those of the World Bank or the IMF. 


\section{Introduction}

Recent growth trends in OECD economies have renewed interest by policy makers and analysts on the sources of economic growth. Some countries, including the United States, have been able to revert the long-standing slowdown in multifactor productivity growth - the standard proxy for technological progress -- while others (mainly in Continental Europe) have persisted along a declining productivity growth path, or have even experienced a protracted stagnation in output growth (as in Japan). These striking differences in growth patterns have been related to the different ability of countries to innovate in the high-tech sector (e.g. information and communication technology, ICT) and to adopt new and highly-productive equipment. Can cross-country differences in innovation and adoption of high-tech be explained by greater returns to such activities in certain countries? And, are there appropriate business climate conditions that provide stronger incentives for firms to innovate and adopt new technologies? If this is indeed the case, is there a role for policy makers for improving business climate conditions? To date, the empirical evidence on these issues is scant.

Much of the recent growth literature has either used accounting techniques to decompose aggregate GDP and productivity growth into their main driving forces (see e.g. Jorgenson and Stiroh, 2001; Olinel and Sichel, 2001), or regression techniques to assess the long-run process of cross-country economic convergence (see e.g. Mankiw et al., 1992; Barro and Sala-i-Martin, 1995). The latter strand of literature has also been extended to consider differences in technology growth rates across industries and countries (see e.g. Bernard and Jones, 1996a,b; Harrigan, 1997a,b). These studies largely concentrate on the "traditional" determinants of growth, i.e. the accumulation of reproducible factor inputs with the possible inclusion of human and knowledge capital. At the same time, however, sector and micro-level studies have pointed to the importance of market conditions for firms' decision to innovate and adopt new technologies (Caves et al., 1998; McKinsey Global Institute, 1997; Baily and Gerbach, 1995; Nickell, 1996; Blanchflower and Machin, 1996; Disney et al., 2000). These studies offer important insights on the behavior of individual firms and specific markets, but because of their micro-oriented nature do not easily allow assessment of the importance of institutions and policy across countries.

This paper offers a contribution to the debate about the role of policy and institutions for productivity and output growth along two dimensions. First, we use harmonized two-digit industry-level data for a set of industrial economies to shed light on productivity convergence across countries and on the role of investment in human and knowledge capital. Our model allows for different patterns of cross-country convergence in multifactor productivity in different industries, while testing for the importance of human capital and R\&D in fostering productivity, either directly or indirectly, via the process of technology adoption. We also consider the possibility that the impact of technological catch-up, as well as of human capital and R\&D, may differ depending on the underlying technology characteristics of each industry. Second, we assess the role of labor adjustment costs and bargaining regimes for productivity growth. In particular, we focus on hiring and firing costs that, by raising labor adjustment costs, may curb incentives to foster internal efficiency through the adoption of leading technologies and innovation (see e.g., Audretsch and Thurik, 2001; Hobjin and Jovanovic, 
2001). Likewise, we look at different wage bargaining systems that, by shifting part of the innovation rents to workers, may reduce the expected returns of innovative activity (Teulings and Hartog, 1998). Our working hypothesis is that these factors may be of particular importance in a period characterized by the rapid diffusion of a new technology (ICT), which requires significant organizational and skill changes (see e.g. Baily, 2002 and Bresnahan et al. 2002).

The paper is organized as follows. Section 1 describes the main features of recent growth trends in OECD countries. In Section 2, we present our productivity model and highlight the potential role of innovation (proxied by R\&D), human capital and labor market regulations and institutions for industry productivity growth. The dataset used in our empirical analysis -- 17 manufacturing industries in 18 OECD countries over the 1984-1998 period -- is presented in Section 3, while our empirical results are discussed in Section 4. Finally, we draw some concluding remarks in Section 5.

\section{Recent growth trends}

\section{Output, productivity and employment patterns}

Much of the discussion about economic growth in recent years has been motivated by a widespread perception that some countries, most notably the United States, have experienced an acceleration in growth patterns while others, mainly in Continental Europe and Japan, have shown a sluggish growth. This perception is largely confirmed by a simple comparison of average growth rates over the past decade (Table 1). Here we use cyclically-adjusted series to control for differences in business cycle conditions across countries. ${ }^{1}$ For the OECD area as a whole, trend GDP per capita growth rates slowed down in the 1990s as compared to the previous decade. However, there has been a fairly widespread pick up in growth in the second half of the decade in most countries. This aggregate pattern, however, hides marked differences across regions and individual countries: while GDP growth has accelerated in the United States and Canada, it has slowed down in EU15. The latter pattern is largely due to the poor growth performance of most large EU economies, while some (mainly small) countries have shown clear signs of acceleration in growth.

The table also shows how these different growth patterns have come about. In particular, the first three columns shows how GDP growth in the business sector ${ }^{2}$ can be decomposed into growth in total hours worked and growth in hourly productivity, while the remaining two columns shows the driving forces of hourly productivity, namely changes in capital/labor ratio and multifactor productivity (MFP) growth. Labor productivity growth accounts for at least half of GDP growth in most OECD countries and considerably more than that in many of them. Notwithstanding differences

1. Indeed, over the 1990s business cycles were largely a-synchronized across OECD countries and this may lead to inaccurate cross-country comparisons. In most of this section, we use cyclically-adjusted series obtained by applying an extended version of the Hodrick-Prescott filter where the well-known end-of-sample problem is minimized by prolonging the time series out of sample using the average growth rates observed over the entire decade. See Scarpetta et al., (2000) for more details.

2. The business sector is defined as the total economy minus Community, Social and Personal Services. 
in labor productivity growth rates across countries, it is noticeable that the overall dispersion (last two rows in the Table) did not change in the 1990s as compared with the 1980s, despite the significant widening of GDP growth rates. A key factor to reconcile growing disparities in GDP per capita growth rates in a context of broadly stable differences in labor productivity growth is a divergence in employment and hours patterns. Significant increases in total hours worked in Ireland, the Netherlands, Spain, the United States and Australia contrast sharply with slumps in Japan, and a number of European countries.

The table also suggests significant differences in the drivers of labor productivity. In most European countries, high (or even rising) productivity growth rates have been achieved by a marked process of capital deepening, which, given the poor employment performance, was largely due to substitution of labor with capital rather than to strong investment in physical capital (see also Scarpetta et al. 2000 for more details). In contrast, labor productivity has been driven by a combination of capital deepening and growth in MFP (i.e. a proxy for technical progress) in Australia, Ireland, Canada, Norway, New Zealand and the United States. As shown in the table, these are the countries where most of the drivers of growth have improved leading to acceleration in overall GDP growth.

The group of countries that have enjoyed better economic performance -- through a combination of higher employment, investment and acceleration in MFP -- include all of those that have implemented significant structural reforms over the past decade (e.g. Australia, Ireland, New Zealand) or where underlying market conditions have always been favorable (e.g. United States). ${ }^{3}$ By contrast, growth performance has been lower in a number of (European) countries where structural reforms have lagged behind. This preliminary evidence is appealing and seems to support our interest for looking at the structural factors influencing market behavior.

Productivity growth has also differed significantly across manufacturing industries within each country (Chart 1). In the United States and Japan, productivity growth was primarily driven by high-tech industries in the 1990s. By contrast, in most European countries, industries adopting low or intermediate technologies played a more important role in aggregate manufacturing productivity growth. Differences in industry-specific conditions across countries, as well as regulations and institutions affecting firms' behavior are likely to underlie some of the cross-country variance in these industry productivity growth rates and in the technological specialization of countries. In the next section we focus on the possible role of regulations and institutions in the labor market as a possible factor driving productivity via its impact on the incentives to innovate and adopt leading technologies.

\section{The links between regulations and institutions on the labor market and productivity: some theoretical considerations}

What is the role of labor market regulations and institutions in the process of technological adoption and innovation? It should be stressed at the outset that these regulations and institutions are primarily

3. For more details on recent reforms in labor and product markets see OECD (1999). 
designed to ensure socially desirable outcomes rather than promote productivity growth. But by raising labor costs and the costs of workforce adjustment, they may also reduce incentives for firms to expand and innovate as well as hire more workers with negative economic and social effects. Traditional growth models tend to suggest that, to the extent that labor market rigidities reduce the equilibrium level of employment, they also negatively affect economic growth. This is because, ceteris paribus, a lower level of employment reduces the marginal product of capital and the incentives to save and invest. ${ }^{4}$ Likewise, regulations that raise the cost of adjusting factor inputs, including labor, are likely to reduce the expected returns on innovation or investment aimed at adopting new technologies with detrimental effects on long-term growth.

Three main aspects of labor market policy and institutional settings seem to be more closely related to the incentive for firms to expand and innovate, although the links are often complex: $i$ ) the system of industrial relations; ii) the costs of hiring and firing (proxied by the stringency of Employment Protection Legislation, EPL); and iii) the possible interactions between industry-specific characteristics of the technology and EPL, which lead to different human resource strategies.

It can be argued that bargaining regimes affect both the size of innovation and technology adoption rents, through their impact on the cost of pursuing these activities, and the scope for the firm to appropriate these rents rather than sharing them with workers or other firms (see notably Boyer, 1988, and Hall and Soskice, 2001). In decentralized wage-bargaining regimes, incentives to innovate and adopt new technologies depend crucially on workers' bargaining power. The risk of hold-up can be partly mitigated when bargaining occurs at the national level (or at the industry level but with economy-wide co-ordination) and sets the general frame of the wage schedule. In such a case, the reservation wage is fixed for all lower-level bargaining units and is adjusted mainly in response to aggregate shocks. As a consequence, the firm's incentive to undertake innovative investment no longer depends on the bargaining power of its own workers (Teulings and Hartog, 1998).

Hiring and firing restrictions may raise the cost of labor adjustment, which is often needed after innovations have been introduced (see e.g. Cappelli, 2000). The effects of these restrictions on productivity and innovation are, however, likely to be mediated by industrial relation regimes. Broadly speaking, in countries where wage negotiations are decentralized, firms tend to adjust their workforce while innovating by hiring adequately skilled workers on the labor market. Conversely, in centralized or sectoral wage bargaining systems, wages are more compressed and firms, despite finding more difficult to attract high skilled workers on the external market, gain from training their own workers (as there is a greater wedge between productivity and wages at high skill levels). ${ }^{5}$ In addition, countries with centralized or sectoral wage bargaining systems also tend to have

4 This standard view is, however, challenges by some endogenous growth models. For example, Bean and Pissarides (1993) show that in an overlapping generations model, an increase in the bargaining power of workers may boost growth: if youths are assumed to work and save and older people to consume and reap the returns from capital, then a shift in bargaining power towards labor may well increase savings, investment and ultimately long-term growth.

5. Lynch (1994), Blinder and Krueger (1996) and Acemoglu and Pischke (1999b) offer some evidence of more firm-sponsored training in more coordinated countries. 
comparatively high hiring and firing costs. The combination of wage compression and high labor adjustment costs tend to favor a process of competence accumulation based on firm-supported training and on-the-job learning.

Wage compression may not, however, be a sufficient condition for firms to rely on the internal labor market to adapt their work force and, ultimately, for the decision to innovate and/or adopt a new technology. Another feature of industrial relation system plays a crucial role: the degree of co-ordination among employers. ${ }^{6}$ Coordination is implicit in highly centralized wage setting systems but also exists in some countries with predominantly sectoral bargaining systems. In coordinated countries, there is only a limited variability of wage offers across firms, thereby reducing the scope for poaching (Teulings and Hartog, 1998; Acemoglu and Pischke, 1999a). Likewise, co-ordination often leads to close inter-firm practices where poaching is considered as unfair behavior (see Blinder and Krueger, 1996; Casper et al., 1999).

The potential effects of bargaining regimes and EPL on the incentives to innovate and adopt new technologies may also depend on the technological characteristics of the sector in which firms operate. It can be argued that in low-tech industries high firing cots are likely to lead to higher adjustment costs, with possible negative effects on innovation and adoption. In high-tech industries the effects of EPL may depend on the technological trajectory of the sector. For example, Saint-Paul (2002) suggests that a high firing cost economy may tend to specialize in "secondary innovation" -- i.e. innovation that increases efficiency in the production of existing goods, as opposed to "primary innovation" that leads to new goods. More generally, when technological progress is cumulative (i.e. further innovations along the same trajectory), then investing in the internal labor force may be an effective way to overcome high firing costs. This is not the case if technological progress leads to frequent shifts in the type of physical and human capital required in the production process. In this latter case, firms have to rely on the external labor market which may be costly when EPL is very strict. ${ }^{7}$

All in all, there are a number of theoretical links between labor market institutions and innovation, adoption of new technologies and, ultimately, productivity performance. Chart 2 offers an illustration of the possible links between industrial relations regimes and EPL on the one hand and productivity performances on the other hand. Industrial relations regimes are identified by a summary indicator of corporatism, which combines two aspects: $i$ ) the level of bargaining: centralized, intermediate (at sector or regional), or decentralized (firm level); and $i$ ) the degree of coordination among employers'

6. An industrial relations system can be said to be coordinated when: i) the wage-bargain occurs in a centralized way or co-ordination among employers and/or trade unions sets a uniform band of wages; ii) employers and trade unions co-operate as regard to decision-making inside the firm; and iii) business associations have an active role in solving free-riding problems across firms (Carlin and Soskice, 1990).

7. Empirical evidence indeed suggests countries with coordinated industrial relations systems and relatively stringent employment protection (e.g. Germany, Austria) have stronger technological comparative advantage in industries characterized by cumulative technological progress than countries with decentralized wage bargaining, no co-ordination and low EPL (e.g. United States, but also United Kingdom and New Zealand more recently) (see Bassanini and Ernst, 2002). 
associations. As discussed above, this combined variable allows consideration of cases where cooperation between employers in an industry bargaining setting (e.g., Germany and Austria and, more recently, Italy, Ireland, the Netherlands with the income policy agreements) may be an alternative, or functionally equivalent, to centralized systems, thereby mimicking their outcomes. ${ }^{8}$

Bearing in mind the very tentative nature of these bivariate correlations, Panel A suggests no apparent relationship between the degree of corporatism and the acceleration in MFP growth. By contrast, Panel B suggests a negative relationship between labor adjustment costs and MFP acceleration. Obviously, these correlations do not take into account the complex interactions between different institutional and technological factors shaping productivity developments. Thus, in the next section of the paper, we further assess these possible links estimating productivity equations across a set of industries in the OECD countries over the past two decades.

\section{The MFP model}

Our empirical model starts with a standard production function (in country $i$ and sector $j$ ), under perfect competition and constant returns to scale. This can be formalized as follows:

$$
Y_{i j t}=A_{i j t} \cdot F_{i j}\left(L_{i j t}, K_{i j t}\right)
$$

where $\mathrm{Y}$ is output, $F_{i j}(\cdot)$ is a country/sector-specific production function assumed to be homogeneous of degree one and exhibits decreasing returns to the accumulation of each factor of production; and $A_{i j t}$ is a Hicks-neutral parameter of technological efficiency or multifactor productivity (MFP), ${ }^{9} K$ is physical capital and $L$ is labor. Assuming a translog production function and taking logs yield:

$$
y_{i j t}=a_{0 i j t}+a_{1 i j t} \cdot l_{i j t}+a_{2 i j t} \cdot k_{i j t}+a_{3 i j t} \cdot l_{i j t}^{2}+a_{4 i j t} \cdot k_{i j t}^{2}+a_{5 i j t} \cdot l_{i j t} \cdot k_{i j t}
$$

In order to assess the driving forces of MFP growth, we extend the conventional endogenous growth model - in which technological efficiency is generally expressed as a function of knowledge and a residual set of influences (Aghion and Howitt, 1998) -- by assuming that, within each industry, the level of efficiency depends on country and industry characteristics as well as technological and organizational transfer from the technology-leader country $(i=L)$ (e.g. Bernard \& Jones, 1996a, 1996b; Griffith et al. 2000; Harrigan, 1999; Dollar and Wolff, 1994). In this context, technological efficiency for a given industry $j$ of country $i$ at date $t\left(a_{i j t}\right)$ can be modeled as an auto-regressive distributed lag $\operatorname{ADL}(1,1)$ process in which the level of efficiency in a given country/industry is co-integrated with that of the technological frontier country $L$. This implies that MFP growth in the frontier country leads to faster MFP growth in follower countries by widening the production

8. The distribution of countries according to the different aspects of collective bargaining and changes over time is presented in Elmeskov et al. (1998).

9. Technical change is "Hicks neutral", or "output augmenting", when it can be represented as an outward shift of the production function that affects all factors of production in the same proportion. 
possibility set. The leader country is defined as the country with the highest level of MFP. Hence, multi-factor productivity for a given industry $j$ of country $i$ can be modelled as follows: ${ }^{10}$

$$
\ln A_{i j t}=\beta_{1 j} \ln A_{i j t-1}+\beta_{2 j} \ln A_{L j t}+\beta_{3 j} \ln A_{L j t-1}+\omega_{i j t}
$$

where $\omega$ stands for all non-observable factors influencing the level of efficiency. Under the assumption of long-run homogeneity for each industry $j\left(1-\beta_{l j}=\beta_{2 j}+\beta_{3 j}\right)$ and rearranging equation [3] yields the convergence equation:

$\Delta \ln A_{i j t}=\beta_{2 j} \Delta \ln A_{L j t}-\left(1-\beta_{1 j}\right) \ln \left(A_{i} / A_{L}\right)_{j t-1}+\omega_{i j t}$

where $\beta_{2 j}$ captures the instantaneous effect of changes in growth of the leader country; $\left(1-\beta_{l j}\right)$ indicates, for each industry, the pace of technological transfer; $\ln \left(A_{i} / A_{L}\right)_{j-1}$ is the technology gap between country $i$ and the technology leader and $\omega_{i j t}$ includes all other influences on technological efficiency. In particular, $\omega_{i j t}$ can be decomposed into: i) a vector of covariates $\left(V_{i j t}\right)$, including structural features (e.g. human capital, $H ; R \& D$ ) as well as labor market regulations and institutions potentially affecting the level of efficiency; ii) unobserved country and industry effects $\left(f_{i}, g_{j}\right.$, respectively); iii) world macroeconomic shocks $\left(d_{t}\right)$; and iv) a serially uncorrelated error term. $\left(\eta_{i j t}\right)$ :

$$
\omega_{i j t}=\sum_{k} \gamma_{k} V_{k j i t-1}+f_{i}+g_{j}+d_{t}+\eta_{i j t}
$$

\section{where $V_{k}$ includes ( $H, R \& D$, labor market regulations etc.)}

Following Griffith et. al (2000) we also test the hypothesis that R\&D and human capital affect productivity not only directly, but also indirectly by easing technological adoption. The rationale is that both R\&D and human capital may be important for technology transfer because they help fostering the ability of firms to make the best use of new technologies (i.e. their absorptive capacity) Assuming for simplicity a linear relationship between each of these factors $\left(x_{s}\right)$ and the rate of technology transfer to non-frontier countries, we can re-write equation [4] as follows

$$
\begin{aligned}
\Delta \ln A_{i j t}= & \delta_{i j} \Delta \ln A_{L j t}-\sigma_{1 j} \ln \left(A_{i} / A_{L}\right)_{j t-1}-\sigma_{2 j} x_{i j t-1} \cdot \ln \left(A_{i} / A_{L}\right)_{j t-1}+ \\
& +\sum_{k} \gamma_{k} V_{k j j t-1}+f_{i}+g_{j}+d_{t}+\eta_{i j t}
\end{aligned}
$$

where $\sigma_{l j}=\left(1-\beta_{1 \mathrm{j}}\right)$. 
From equations [4] and [6] it is clear that the coefficient of the technology gap measures the speed of (conditional) convergence to the long-run steady state level of technological efficiency. Moreover, in the presence of technological convergence, the technological distance between each country/industry and the leader converges to a constant value. This implies that the vector of covariates as well as the country and industry fixed effects translate only into differences in efficiency levels, and not into permanent differences in growth rates of technological efficiency.

Given the translog production function, the rate of growth of technological efficiency $(\Delta \operatorname{Ln} A)$ can be proxied by the so-called Solow residual, or multifactor productivity, as follows:

$$
\Delta L n A_{i j t}=\Delta L n M F P_{i j t}=\Delta y_{i j t}-\frac{1}{2} \cdot\left(\alpha_{i j t}+\alpha_{i j t-1}\right) \cdot \Delta l_{i j t}-\left(1-\frac{1}{2} \cdot\left(\alpha_{i j t}+\alpha_{i j t-1}\right)\right) \cdot \Delta k_{i j t}
$$

while the following superlative index is used as a measure of the level of MFP:

$$
M F P_{i j t}=\frac{Y_{i j t}}{\bar{Y}_{j t}} \cdot\left(\frac{\bar{L}_{j t}}{L_{i j t}}\right)^{\widetilde{\alpha}_{j i t}} \cdot\left(\frac{\bar{K}_{j t}}{K_{i j t}}\right)^{1-\widetilde{\alpha}_{j i t}}
$$

where a bar denotes a geometric average over all the countries for a given industry $j$ and year $t$ and $\widetilde{\alpha}_{i j t}=\left(\alpha_{i j t}+\bar{\alpha}_{j}\right) / 2$ where $\alpha_{i j t}$ is the labor's share in country $i$ and industry $j$ and $\bar{\alpha}_{j}$ is the cross-country average for industry $j$. The MFP index has the desirable properties of transitiveness that makes it possible to compare national productivity levels (see Caves et al. 1982). However, the comparison of productivity levels also requires the conversion of underlying data into a common currency, while also taking into account of differences in purchasing powers across countries. These issues are discussed in the next section.

\section{The empirical analysis}

\section{The data}

Our main source of data is the OECD STAN-2002 database (see the appendix for further details). We have also compiled data on occupational skills (employment and wages) and hours worked by sector and country from various sources.

Given data availability, we adopt a value-added measure of MFP. Labor input is based on total hours worked using industry-level data, and the capital stock series had to be constructed for a few country/industries using the perpetual inventory method (see appendix). The calculation of MFP also requires estimates of the partial elasticity of output to labor. Under perfect competition, the partial elasticity can be proxied by the share of labor compensation in total costs. The latter, however, is 
volatile, reflecting short-run fluctuations in demand conditions and possibly the fact that wages are not negotiated on an annual basis. In order to minimize these short-run fluctuations, the share of labor compensation was regressed on country-industry specific fixed-effects and on the logarithm of capital-labor ratio. Fixed effects account for unobserved factors influencing the technology used (such as endowments, available technologies, institutional factors). Next, we use as a country/sector-specific measure of the labor share the fitted value from this equation, which accounts for country-industry fixed components plus variations due to changes in the capital intensity.

Finally, the calculations of MFP levels requires the use of comparative product price levels across countries in order to convert the value of production to common units, while taking into account differences in the purchasing power of each country's currency. Ideally, comparative product prices should be measured at the producer level, but survey data on production prices are usually available only for a few countries and for even fewer products. Thus, we use estimates of industry-specific expenditure PPPs. ${ }^{11}$

Data on R\&D intensity are drawn from the OECD ANBERD database. R\&D intensity is defined as the ratio Business Expenditure in Research and Development (BERD) to value-added. Value-added is from the main dataset discussed above. Different measures of human capital were considered. First, macro-economic proxy for general human capital, such as the proportion of individual with secondary school attainment and the average number of years of schooling of employment were considered. The coefficients on either of these two variables turned out to be statistically non significant in the MFP regressions. The alternative indicator is an industry-level proxy of human capital, based on the skill composition of employment and relative wages by skill level. Thus, the measure of human capital is defined by (the subscripts $j, i$ and $t$ are omitted):

HumanCapital $=\log \left[1+\frac{\omega_{H W h}}{\omega_{L W h}} \cdot \frac{L_{H W h}}{L}+\frac{\omega_{H B l}}{\omega_{L B l}} \cdot \frac{L_{H B l}}{L}\right]$

where $\omega_{H W h}, \omega_{L W h}, \omega_{H B l}, \omega_{L B l}$ are respectively the wage rate for the white-collar high-skill, whitecollar low-skill, blue-collar high-skill and blue-collar low-skill workers. $L_{H W h}, L_{H B l}$ and $L$ are respectively white-collar high-skill employment, blue-collar high skill employment and total employment. Thus, this measure is rising with the wage premium of (white-collar and blue-collar) skilled workers relative to unskilled workers, weighted with the proportion of (white-collar and bluecollar) skilled workers in total employment (see the appendix for a description of the data).

11. The alternative is to use aggregate purchasing power parities (PPPs) for GDP as often done in the empirical literature (see e.g., Bernard and Jones, 1996a,b). However, aggregate PPPs are problematic if relative prices evolve differently across countries (Harrigan, 1997a). For example, Sørensen (2001) shows that while relative productivity levels are independent of the choice of the base year, using PPPs for total GDP leads to different degree of convergence depending on the base year chosen for PPPs. This may be due to the fact that relative prices of manufacturing have evolved differently across countries, but may also reflect the fact that PPPs for total GPD have improved over time. 
In the next step, this variable is regressed on: 1) country specific and industry specific fixed effects; and 2) time dummies that are country and industry specific. The predicted value is used as a measure of human capital in the MFP regressions reported in the main text. ${ }^{12}$

Given the discussion in the previous section, we consider two main indicators of policy and institutions: i) an indicator of hiring and firing costs; and ii) an indicator of the industrial relations regime in each country. Hiring and firing costs are proxied by the indicator of the stringency of employment protection legislation $(E P L)$. The EPL indicator refers to nation-wide regulations and laws and thus does not vary across industries in a given country, even if the related hiring and firing costs may well differ depending on specific characteristics of each industry (see Box 1). We have also used a measure of EPL that interacts with the size of firms in each industry. Since the average size of firms in a given industry is likely to be endogenous to market conditions, including institutional factors, we have used the cross-country firm size average for each industry (across a sample of ten OECD countries) and applied it to all countries. Industrial relations regimes are identified by a summary indicator of corporatism as discussed above. Moreover, we also test for different patterns of productivity growth depending on technology regimes by dividing the industry sample into two main groups: low-tech and high tech industries (see Box 1).

\begin{abstract}
Box 1. Indicators of Employment Protection, Wage Bargaining and Technological Groups The indicators of employment protection legislation (EPL)

The indicators of employment protection legislation are available for two periods (late 1980s and 1998) and focus on both regular and temporary contracts (see Nicoletti et al. 1999). Regulations for regular contracts include: i) procedural inconvenience that employers face when trying to dismiss a worker; ii) advance notice of the dismissal and severance payments; and iii) prevailing standards of, and penalties for, "unfair" dismissals. Indicators of the stringency of EPL for temporary contracts include: i) the "objective" reasons under which they can be offered; ii) the maximum number of successive renewals; and iii) the maximum cumulated duration of the contract. The EPL indicator used in the econometric analysis is time-varying, with the shift in regime from the late 1980s stance to that of 1990s being defined on the basis of information about the timing of major EPL reforms (concerning both temporary and regular workers) in OECD countries. It should be stressed that the EPL indicators are constructed on the basis of differences in regulatory settings across OECD countries. The focus is on excessive regulation that could unnecessarily restrict market mechanisms, because it makes reallocation of resources difficult, hindering the response of the economy to structural changes.

The indicator of EPL interacting with industry firm size uses the cross-country average size of firms in each industry to minimize possible endogeneity of the firm dimension to regulations. The cross-country average of firm size in each industry is calculated using a sample of 9 OECD countries. For each country, data are from the business register or the social security administration and cover all firms with one or more employees. See Bartelsman et al. (2003) for details.
\end{abstract}

continued

12. The coefficient on human capital remains significant with the same sign if the original variable is used instead of the predicted one in the productivity regressions. The use of the original variable, however, reduces somewhat the sample size, and thus we decided to concentrate on the predicted human capital variable. 


\section{Wage bargaining regimes}

The summary indicator of the bargaining system combines two aspects: i) the level of bargaining: centralized, intermediate (at sector or regional), or decentralised (firm level); and ii) the degree of co-ordination among, on the one hand, employers' associations and, on the other, trade unions. This combined variable allows consideration of cases where co-operation between employers and unions in an industry bargaining setting (e.g., Germany and Austria and, more recently, Italy, Ireland and the Netherlands with the income policy agreements) may be an alternative, or functionally equivalent, to centralized systems, thereby mimicking their outcomes. The distribution of countries according to the different aspects of collective bargaining and changes over time is presented in Elmeskov, Martin and Scarpetta (1998). The indicator of corporatism is time-varying and consider changes in the predominant level of wage bargaining in the OECD countries or in the degree of co-ordination amongst social partners over the period covered in the empirical analysis.

\section{Technological groups}

The industrial organization literature suggests three main elements that characterise market conditions across industries. First, differences in market power relate to differences in entry barriers, due to exogenous technological conditions, such as economies of scale (see e.g. Panzar, 1989) and scope (Baumol et al., 1982). Second, it has been argued that entry barriers may be due to high sunk costs rather than economies of scale. Finally, more recent research has focused on horizontal and vertical product differentiation (Eaton and Lipsey, 1989). When consumers cannot rank products unambiguously by quality, the taste for variety is valued per se and products can be considered to be differentiated horizontally. Products can be considered as differentiated vertically when consumers can rank them by quality.

In practice, the degree of economies of scale and scope, sunk costs and product differentiation are often combined in different ways, but depending on their relative importance, one (or few) will dominate the others, leading to a reduced number of market structure prototypes. In practical terms a simple classification can be made based on the returns to innovation and the degree of market concentration (see also Sutton, 1998, 2000). If the returns to innovation (e.g. R\&D) are low, the fraction of revenue devoted to such activity will be low: this configuration indicates low-tech industries where production processes and product design are fairly standardised. In this context set-up costs are low and a large number of firms compete fiercely on price, which is close to marginal cost. If the returns to innovation are high, firms will invest heavily in technologies that improve process and products.

The nature of competition, the impact of given policy and institutional settings and, ultimately, productivity performance may vary across these different market structures. For example, high mark ups could be taken as a sign of market power in industries with low $R \& D$, although they may well be an indication of innovation rents in those with high R\&D (Oliveira Martins and Scarpetta, 1999).

\section{Empirical Results}

The empirical analysis covers 17 manufacturing industries in 18 OECD countries ${ }^{13}$ over the period 1984-1998. The technological gap term, representing the distance from the technological frontier, is proxied by the difference between the MFP level in a particular industry and the highest level amongst countries for that industry. Although crude, this measure broadly confirms expectations about which countries and regions tend to be at the forefront of technology in certain fields. For example, the estimated levels of MFP (see Appendix Table) reveals that the United States, Canada and Japan were often at the frontier (or close to it) in most industries considered in the 1980s and 1990s. However, especially if the lower levels of hours worked are taken into account, a number of European countries were also relatively close to the frontier. The comparison of MFP levels also 
suggests that in only a few cases does the identity of the frontier remain constant; i.e. in most industries, some countries leapfrogged others in terms of technology leadership. As shown below, however, what matters for productivity growth is the distance from the technological frontier -- which captures the potential for technology transfer -- rather than the identity of the frontier itself. ${ }^{14}$

In order to compare the empirical results with those of previous studies, Table 2 presents different specifications of a baseline equation in which MFP growth is regressed only on the industry leader and the technology-gap term. ${ }^{15}$ The technology-gap term (RTFP) enters negatively and is significant at conventional levels in all specifications, suggesting that, within each industry, countries that are further behind the frontier experience higher rates of productivity growth (see below for an exception in high-tech manufacturing industries). By contrast, we found no evidence of a strong short-run effect of the MFP growth in the frontier country $\left(\triangle M F P_{\text {leader }}\right)$ on other country/industries. The table also indicates a positive effect of human capital and R\&D activity on productivity growth, as would be expected. ${ }^{16}$ As discussed above, we also test for a possible interaction between both human capital and $R \& D$ and the technology gap. The results do not lend a strong support to this idea: in both cases the interaction term is not statistically significant at conventional levels, and in the case of R\&D is even wrongly signed (i.e. R\&D seems to lead to divergence, see below).

The right-hand-side specifications in Table 2 also test for a differentiated impact of technology catch up and $\mathrm{R} \& \mathrm{D}$ on productivity depending on the underlying technology level characterizing each industry. As discussed in the previous section, industries are divided into a low-tech group (LT in the

14. In Scarpetta and Tressel (2002) we run a detailed sensitivity analysis of the baseline MFP equation. In particular, we used different measures of MFP (level and growth) based on: i) a measure of labor input that does not include hours worked; ii) a measure of labor input that controls for changes in the composition of employment by skills; and iii) a measure of the labor share that takes into account the existence of positive mark-ups of prices over marginal costs (these are from Oliveira Martins and Scarpetta, 1999). The estimated coefficients of the baseline productivity equation are robust to these different measures of MFP.

15. All specifications control for country and industry fixed effects. Moreover, all equations include time dummies to control for common aggregate shocks that affect MFP in all countries. Since there is evidence of heteroschedasticity in our data, we used the Huber-White-Sandwich estimator of variance. We also excluded outliers using a procedure based on the residual and leverage of each observation, based on the notion of the influence curve. The influence curve assesses the asymptotic marginal effect of adding a specific observation i on the coefficient estimates, on the basis of the original regression model. The influence curve is an asymptotic concept. However, the DFITS or Welsch-Kuh distance and the Welsch distance are two indicators used in the paper to approximate empirically the influence curve and detect influential observations from it (Chatterjee and Hadi, 1988). We did not use the instrumental variables approach (e.g. Arellano and Bond, 1991) to correct for small-sample downward lagged dependent variable bias because of the difficulty in using lagged observations for some of the policy variables and, more importantly, because the bias declines with the number of time observations and for $\mathrm{t} \approx 15$ the bias is small (see Nickell, 1981).

16. This positive association between industry-specific human capital and productivity should not be over-emphasized because of possible problems of reverse causality. Strong productivity performance is likely to stimulate the accumulation of human capital by firms and attract highly qualified workers. This possible reverse causality problem can be particularly serious at the industry or firm level, e.g. firms/industries with high productivity patterns are more likely to invest in highly-skilled workers, by hiring them or recurring to internal training. 
table) and a high-tech group (HT in the table): see the appendix for the industry classification. It is noticeable that technology convergence seems to take place mainly in low-tech industry, while in the high-tech group of manufacturing industry there is evidence of divergence: i.e. technology leaders tend to enjoy higher productivity growth, ceteris paribus, that followers. ${ }^{17}$ It is also interesting to notice that R\&D has a stronger (and statistically significant) effect in high-tech industries than in low-tech industries. Moreover, contrary to the overall manufacturing, there is evidence of an interaction between $R \& D$ and the technology gap in high-tech industries, but the sign is positive, suggesting greater returns from R\&D of leading countries, compared with followers. ${ }^{18}$ High-tech industries are often dominated by large, established firms and the presence of barriers for new innovators. Returns to R\&D in these industries are likely to be larger than in low-tech ones, possibly leading to persistent technological leadership. Finally, the results suggest no significant difference in the estimated effect of human capital on productivity depending on the underlying technology level. ${ }^{19}$

These results on technology catch up and the impact of R\&D activity in high-tech industries may offer a rationale for the weaker productivity performance in ICT-related industries in Continental Europe compared with the United States and a few small countries (see amongst others Scarpetta et al. 2000). The fact that Continental European countries have accumulated a technology gap in ICTrelated industries, instead of leading to stronger productivity growth as standard convergence theory would suggest, is further dragging behind these countries compared with the technology leaders. In this context, innovation gives a further advantage to the technology leaders.

In Table 3 the analysis is extended to cover labor market regulations and institutions. Available data do not allow differentiating these labor market indicators by industry. In particular, the indicator of the stringency of employment protection legislation (EPL) varies across countries and (for some of them) over time, but is identical across industries. The implication of this is that country dummies are highly correlated with this country-wide indicator and had to be removed. However, country dummies may account for a more diversified set of factors characterizing countries in the sample, over and above EPL and their exclusion may lead to an omitted-variable problem. ${ }^{20}$ Two tests were performed to assess this potential problem. First, we run the standard RESET test of misspecification. Second, we test for the sensitivity of the coefficients of the other variables to the elimination of the country dummies. In any event, in the specifications without country-fixed effects, standard errors

17. The F test rejects the hypothesis of equality of coefficients on the technology gap variable between the two technology groups at the 5 per cent level.

18. In this case, the $\mathrm{F}$ test rejects the hypothesis of equality of the $\mathrm{R} \& \mathrm{D}$ coefficients and of the interaction coefficients (R\&D*RTFP) between the two technology groups at the 5 and $1 \%$ level, respectively.

19. The F test cannot reject the homogeneity of the coefficients. Moreover, we tested for a possible differentiation in the interaction coefficient between human capital and the technology gap: both coefficients were not statistically significant and the F-test could not reject the homogeneity of the coefficient.

20. One such factor is the regulatory setting in the product market. However, in another paper we have shown that the inclusion of various indicators of the strictness of product market regulation in the productivity equation does not alter the sign or statistical significance of the estimated coefficients of EPL. See Scarpetta and Tressel (2002). 
and variance-covariance matrix of the estimators are adjusted for cluster level effects on countryindustry using the procedure suggested by Moulton (1986).

The results do not lend support to the idea that different industrial relations regimes per se have a significant impact on productivity. However, differences in these regimes seem to affect significantly the estimated impact of EPL on multifactor productivity. In the first equation in Table 3, the EPL coefficient is negatively signed but statistically insignificant. However, if allowed to vary across the different industrial relations regimes, the negative impact of strict EPL on productivity becomes strong and statistically significant in countries with an intermediate degree of corporatism -- i.e. where sectoral wage bargaining is predominant without co-ordination. This result is consistent with the theoretical considerations discussed above. In particular, strict EPL raises the costs of adjusting the workforce, and this may have a particularly detrimental effect on technology adoption and MFP growth if, in addition, the lack of co-ordination does not offer a firm the required institutional device to guarantee a high return on internal training, because other firms can poach on its skilled workforce by offering higher wages.

It should be noticed that removing the country specific effects from the equation weakens the productivity equation: the RESET test of mis-specification is significant the 5 percent level and some of the estimated coefficients (e.g. human capital) are significantly different from those estimated in the baseline specification with country dummies. To test for the robustness of the EPL results to the inclusion of country-specific effects, we use the interaction term of EPL and the average (across countries) size of firms in each industry. The results largely confirm those based on the simple EPL variable: high labor adjustment costs seem to curb productivity in countries with intermediate level of bargaining and lacking co-ordination. With this industry-specific indicator, we also test for a possible non-linearity in the EPL effect on productivity depending on the average size of firms. This is done by also including the interaction variable in level and squared form in the equation. The estimated coefficient of the interaction term is negatively signed, as expected, but that on the squared interaction variable is positively signed, pointing to the fact that strict EPL has a particular detrimental effect in industries with small average firm size. We have also tested for a differentiated effect of EPL and EPL interacted with average firm size between the two technology regimes. ${ }^{21}$ The results confirm the negative effect of EPL in intermediate bargaining regimes lacking co-ordination and the non-linear effect, but no significant difference in the impact can be detected between the two technology regimes.

The fact that the impact of EPL on productivity also depends on the average size of firms can also be rationalized by the fact that in a number of countries with relatively tight EPL (e.g. Germany, Italy, Portugal) firms below a given size threshold (ranging from 5 to 25 employees) are exempted from certain aspects of the employment protection legislation. More generally, larger units have greater scope for internal reorganization to adjust the production process to a new technology than small ones. This may also offer an additional explanation for the apparent delay in the adoption of the ICT technology in Europe. Recent evidence suggests that new firms tend to be smaller than the average

21 Our results imply that the impact of EPL is negative for firms with less than 400 employees. 
incumbent in most industries, and play an important role in the adoption of ICT (see Scarpetta et al, 2002): high labor adjustment costs may deter entry of such highly innovative firms and thus slow down the adoption of the ICT technology.

\section{Concluding remarks}

In this paper, we present an empirical investigation of the drivers of industry-level multifactor productivity growth for a set of manufacturing industries in 18 OECD economies. We focus on traditional growth factors, including technological catch up, human capital and R\&D as well as institutional factors affecting labor costs.

The results for the whole manufacturing sector are consistent with the standard convergence hypothesis, whereby countries that are further behind the technological frontier tend to experience higher rates of productivity growth, other things being equal. However, allowing for differences in the process of technological catch up across industries indicates a cross-country divergence in high-tech industries where, ceteris paribus, country leaders tend to pull ahead of the others. Moreover, while there is evidence of a positive and significant impact of human capital on productivity growth in all industries, the link between R\&D activity and productivity is strongly influenced by the level and type of technology dominating in each industry. Thus, there is no evidence of R\&D boosting productivity in low-tech industries, but the effect is strong in high-tech industries. In the latter, there is also a strong positive interaction between R\&D and the technology gap, i.e. there are greater returns to $R \& D$ in the leading countries, compared with followers. This is consistent with high appropriability conditions in many high-tech industries in which knowledge and technological progress is strongly cumulative, which gives the technological leader an advantage in the introduction of innovations.

Depending on the industrial relation regime, labor adjustment costs also contribute to explain cross-country differences in industry productivity patterns. High adjustment costs (proxied by the strictness of employment protection legislation) have a strong negative impact on productivity in countries lacking coordination among employers. This is consistent with the view that firms may adopt different strategies to accommodate the workforce to the requirements of new technologies. Firms facing high hiring and firing costs will make greater use of the internal labor market (training) rather than hiring new workers, especially if wage dispersion across skills is limited as in centralized and sectoral wage bargaining systems. However, the expected returns from training will tend to be low if industrial relations do not offer an institutional device (such as coordination among employers) that limits free-riding behavior associated with the possibility for other firms to poach on the pool of trained workers. In these cases, high hiring and firing costs lead to sub-optimal adjustments of the workforce to technology changes and lower incentives for firms to innovate or adopt new technologies with negative effects on productivity performance.

These results may have important implications for developing countries. They clearly point to the fact that productivity convergence cannot be taken for granted, especially in high tech industries, and likely depends on whether the business environment creates appropriate conditions for firms to take 
advantage of new technologies available in the world market. Such conditions include the ability to adapt the workforce to the needs of these new technologies, which in turn depends on industrial relations regimes and labor market regulations. The lack of relative wage flexibility together with high firing costs, as observed in several developing countries, may significantly deter firms from innovating or even adopting new technologies, and thus slow down the technological and economic catch-up process. 


\section{References}

ACEMOGLU, D. and S. PISCHKE (1999a), "The Structure of Wages and Investment in General Training", Journal of Political Economy, Vol. 107, pp. 539-572.

ACEMOGLU, D. and S. PISCHKE (1999b), "Beyond Becker: Training in Imperfect Labor Markets", Economic Journal, Vol. 109, pp. F112-142.

AGHION, P., and P. HOWITT , (1998), Endogenous Growth Theory, Cambridge: Mass.: The MIT Press.

ARELLANO, M. and S. BOND (1991), "Some tests of specification for panel data: Monte Carlo evidence and an application to employment equations", Review of Economic Studies, 58, pp. 277-297.

AUDRETSCH, D.B. and R. THURIK (2001), "Linking Entrepreneurship to Growth”, OECD STI Working Papers - 2001/2, OECD, Paris.

BAILY, M.N. (2002), "The New Economy in Europe and the United States", paper prepared for the Conference "Transatlantic Perspectives on the US and European Economies: Convergence, Conflict and Cooperation, J.F. Kennedy School of Government, April.

BAILY, M.N., and H. GERSBACH (1995), "Efficiency in Manufacturing and the Need for Global Competition", Brooking Papers on Economic Activity: Microeconomics p.307-308.

BARRO, R.J. and X. SALA-I-MARTIN (1995), “Economic Growth”, McGraw-Hill.

BARTELSMAN, E.J., S. SCARPETTA, and F. SCHIVARDI (2003), "Comparative analysis of firm demographics and survival: Micro-level evidence for the OECD countries", OECD Economics Department Working Papers No. 348, Paris.

BASSANINI, A., and E. ERNST (2002), "Labor Market Institutions, Product Market Regulation, and Innovation: Cross-country Evidence”, OECD Economics Department Working Paper $\mathrm{N}^{\mathrm{o}} 316$.

BAUMOL W., PANZAR J. and WILLIG R. (1982), Contestable markets and the Theory of Industry structure, New York: Harcourt Brace

BEAN, C. and C. PISSARIDES (1993), "Unemployment, consumption and growth", European Economic Review 41, pp. 837-854.

BERNARD, A., and C.I. JONES (1996a), "Comparing Apples to Oranges: Productivity Convergence and Measurement across Industries and Countries", The American Economic Review, vol.86 No.5, pp. 1216-38

BERNARD, A., and C.I. JONES (1996b), "Productivity Across Industries and Countries: Time-Series Theory and Evidence", The Review of Economics and Statistics, pp 135-146.

BLANCHFLOWER, D. and S. MACHIN (1996), "Product market competition, wages and productivity: international evidence from establishment-level data", Centre for Economic Performance, Discussion paper No. 286, April.

BLINDER, A. and A. KRUEGER (1996), "Labor Turnover in the USA and Japan: A Tale of Two Countries", Pacific Economic Review, Vol. 1, pp. 27-57.

BOYER, R. (1988), “Technical Change and the Theory of Regulation”, in G. Dosi, C. Freeman, R. Nelson, G. Silverberg and L. Soete (eds.), Technical Change and Economic Theory, London: Pinter. 
BRESNAHAN, T.F., E. BRYNJOLFSSON and L.M. HITT (2002), "Technology, Workplace Organization and the Demand for Skilled Labor: Firm-Level Evidence", Quarterly Journal of Economics, 117(1), pp.339-376.

CAPPELLI, P. (2000), "Examining the Incidence of Downsizing and Its Effect on Establishment Performance", in D. Neumark (ed.), On the Job, New York: Russell Sage Foundation.

CARLIN, W., and D. SOSKICE (1990), Macroeconomics and the Wage Bargain, Oxford: Oxford University Press.

CASPER, S. LEHRER, M. and D. SOSKICE (1999), "Can High-Technology Industries Prosper in Germany? Institutional Frameworks and the Evolution of the German Software and Biotechnology Industries", Industry and Innovation, 6(1), June, pp. 5-24.

CHATTERJEE, S. and A. HADI, (1988) Sensitivity Analysis in Linear Regression, John Wiley.

COUNCIL OF ECONOMIC ADVISORS (2000), "Economic Report of the President - 2000", February, Washington D.C.

CAVES, D. L. CHRISTENSEN and E. DIEWERT (1982), "Multilateral comparisons of output, input, and productivity using superlative index numbers", Economic Journal, 92.

CAVES, R.E. (1998), "Industrial Organization and New Findings on the Turnover and Mobility of Firms", Journal of Economic Literature, Vol. 36:4, pp. 1947-82.

DE LA FUENTE, A. and R. DOMÉNECH (2000), "Human Capital in Growth Regressions: How Much Difference Does Data Quality Make?" OECD Economics Department Working Papers, No 262, Paris.

DISNEY, R., J. HASKEL and Y. HEDEN (2000), "Restructuring and productivity growth in UK manufacturing", CEPR Discussion paper series, No. 2463, May.

DOLLAR, D. and E. WOLFF (1994), "Capital intensity and TFP convergence by industry in manufacturing, 1963-85", in Baumol, W. R. Nelson and E. Wolff (eds.) "Convergence of productivity: cross-national studies and historical evidence", Oxford Univ. Press..

EATON, B.C. and R.G. LIPSEY (1989), "Product Differentiation", in R. Schmalensee and R.D. Willig (eds.), Handbook of Industrial Organization, North-Holland, Amsterdam.

ELMESKOV, J., J. MARTIN and S. SCARPETTA (1998), "Key Lessons for Labor Market Reforms: Evidence from OECD Countries' Experiences", Swedish Economic Policy Review, Vol. 5, pp. 205-252.

GRIFFITH R., S. REDDING and J. van REENEN (2000), "Mapping the two faces of R\&D: Productivity growth in a panel of OECD industries", IFS working paper W00/02.

HALL, P., and D. SOSKICE (2001), Varieties of Capitalism, Oxford: Oxford University Press.

HOBJIN, B. and B. JOVANOVIC (2001), "The Information Technology Revolution and the Stock Market: Evidence", American Economic Review, forthcoming.

HARRIGAN, J. (1997a), "Technology, Factor Supplies, and International Specialisation: Estimating the Neoclassical Model", The American Economic Review, vol.87, No.4, pp. 475-494.

HARRIGAN, J. (1997b), "Cross-country Comparisons of Industry Total Factor Productivity: Theory and Evidence", Federal Reserve Bank of New York, Research Paper no. 9734.

HARRIGAN, J. (1999), "Estimation of Cross-country Differences in Industry Production Functions", Journal of International Economics, 47(2), April, pp. 267-93 
JORGENSON, D.W. and K.J. STIROH (2000), "Raising the Speed Limit: U.S. Economic Growth in the Information Age", Brookings Papers on Economic Activity, 1, pp. 125-211.

LYNCH, L. (1994) (ed.), Training and the Private Sector: International Comparisons, Chicago: University of Chicago Press for the NBER.

MANKIW, G.N., D. ROMER and D.N. WEIL (1992), "A contribution to the empirics of economic growth", Quarterly Journal of Economics, 107, pp. 407-37, May.

McKINSEY Global Institute (1997), Removing Barriers to Growth and Employment in France and Germany, McKinsey.

MOULTON, B.R. (1986), "Random Group Effects and the Precision of Regression Estimates", Journal of Econometrics, Vol. 32, pp. 385-397.

NICKELL, S., D. NICOLITSAS and N. DRYDEN (1997), “What makes firms perform well?”, European Economic Review, 41.

NICKELL, S. (1981), "Biases in dynamic models with fixed effects", Econometrica, 49, pp. 1399-1413.

NICKELL, S. (1996), "Competition and Corporate Performance”, Journal of Political Economy, Vol. 104, pp. 724-746.

NICOLETTI, G., S. SCARPETTA and O. BOYLAUD (1999), "Summary Indicators of Product Market Regulation with an Extension to Employment Protection Legislation", OECD Economics Department Working Papers, $\mathrm{N}^{\mathrm{o}} 226$, Paris.

OECD (1999), The OECD Jobs Strategy: Assessing Performance and Policy, OECD, Paris.

OLINER, S.D. and D.E. SICHEL (2000), "The Resurgence of Growth in the late 1990s: Is Information Technology the Story?", The Journal of Economic Perspectives, 14 (4), pp/3-22.

OLIVEIRA MARTINS, J., and S. SCARPETTA, (1999), "The levels and cyclical behaviour of mark-ups across countries and market structures," OECD Economics Department Working Papers No. 213, Paris.

PANZAR, J. (1989), "Technological Determinants of Firm and Industry Structure," Ch. 1 in Handbook of Industrial Organization, North-Holland

SAINT-PAUL, J. (2002), "Employment protection, international specialisation and innovation", European Economic Review, (46)2 (2002) pp. 375-395.

SCARPETTA, S., A. BASSANINI, D. PILAT and P. SCHREYER (2000), "Economic growth in the OECD area: recent trends at the aggregate and sectoral level", OECD Economics Department Working Papers, No. 248, Paris.

SCARPETTA, S. P. HEMMINGS, T. TRESSEL and J. WOO (2002), "The role of policy and Institutions for productivity and firm dynamics: Evidence from micro and industry data", OECD Economics Department Working Papers No. 329, Paris.

SCARPETTA, S. and T. TRESSEL (2002), "Productivity and Convergence in a Panel of OECD industries: Do Regulations and Institutions Matter? ”, OECD Economics Department Working Papers No. 342, Paris.

SØRENSEN, A. (2001), "Comparing Apples and Oranges: Productivity Convergence and Measurement Across Industries and Countries: Comment", American Economic Review, 91, 4, pp. 1160-1167.

SUTTON, J. (1998), Technology and Market Structure, Cambridge, Mass.: The MIT Press. 
SUTTON, J. (2000), "Rich Trade, Scarce Capabilities, Industrial Development Revisited", Keynes Lecture, British Academy, October.

TEULINGS, C., and J. HARTOG (1998), Corporatism or Competition? Labor Contracts, Institutions and Wage Structures in International Comparison, Cambridge: Cambridge University Press. 
Table 1. Decomposition of growth performance, $1980-2000$

Percentage change at annual rate, trend series

Summary of business sector GDP growth and its components

\begin{tabular}{|c|c|c|c|c|c|c|c|c|c|c|c|c|c|c|c|}
\hline & \multicolumn{3}{|c|}{ GDP } & \multicolumn{3}{|c|}{ Total hours } & \multicolumn{3}{|c|}{ Labour productivity } & \multicolumn{3}{|c|}{ Capital deepening } & \multicolumn{3}{|c|}{ MFP } \\
\hline & \multicolumn{3}{|c|}{$1980-1990^{1} 1990-2000^{2} 1996-2000^{3}$} & \multicolumn{3}{|c|}{$1980-1990^{1} 1990-2000^{2} 1996-2000^{3}$} & \multicolumn{3}{|c|}{$1980-1990^{1} 1990-2000^{2} 1996-2000^{3}$} & \multicolumn{3}{|c|}{$1980-1990^{4} 1990-2000^{5} 1996-2000^{6}$} & \multicolumn{3}{|c|}{$61980-1990^{4} 1990-2000^{5} 1996-2000^{6}$} \\
\hline United States & 3.3 & 3.6 & 4.1 & 2.0 & 2.2 & 2.5 & 1.3 & 1.4 & 1.6 & 2.9 & 2.5 & 3.0 & 0.9 & 1.1 & 1.3 \\
\hline Japan & 4.1 & 1.7 & 1.0 & 0.7 & -0.6 & -0.9 & 3.3 & 2.3 & 1.9 & 6.5 & 5.1 & 4.3 & 2.2 & 1.0 & 0.7 \\
\hline France & 2.3 & 2.1 & 2.6 & -0.9 & 0.1 & 0.8 & 3.2 & 2.0 & 1.8 & 4.0 & 3.1 & 2.7 & 1.9 & 1.0 & 1.1 \\
\hline Italy & 2.5 & 1.9 & 2.1 & 0.1 & -0.1 & 0.5 & 2.4 & 2.0 & 1.6 & 3.2 & 3.0 & 3.0 & 1.5 & 1.0 & 0.7 \\
\hline United Kingdom & 3.1 & 2.0 & 2.6 & 0.7 & 0.7 & 1.2 & 2.3 & 1.4 & 1.5 & 2.8 & 2.8 & 2.8 & 1.0 & 0.7 & 1.0 \\
\hline Canada & 2.7 & 3.1 & 4.0 & 1.5 & 1.6 & 2.4 & 1.2 & 1.5 & 1.6 & 3.5 & 1.4 & 0.9 & 0.6 & 1.3 & 1.7 \\
\hline Australia & 3.5 & 4.1 & 4.5 & 2.1 & 2.0 & 2.2 & 1.4 & 2.1 & 2.2 & 4.4 & 4.1 & 4.5 & 0.6 & 1.3 & 1.4 \\
\hline Austria & 2.4 & 2.7 & 2.6 & 0.2 & 0.1 & 0.0 & 2.7 & 2.6 & 2.7 & 4.4 & 4.4 & 4.3 & 1.8 & 1.6 & 1.5 \\
\hline Belgium & 2.6 & 2.1 & 2.2 & 0.0 & -0.1 & 0.1 & 2.6 & 2.3 & 2.2 & 3.4 & 3.8 & 3.8 & 1.7 & 1.2 & 1.2 \\
\hline Denmark & 2.2 & 2.6 & 3.1 & 0.3 & 0.3 & 1.0 & 1.9 & 2.3 & 2.1 & 3.8 & 2.5 & 2.4 & 1.0 & 1.5 & 1.4 \\
\hline Finland & 2.6 & 2.9 & 4.9 & -1.0 & -0.7 & 1.5 & 3.7 & 3.7 & 3.3 & 3.2 & 0.8 & 0.7 & 2.4 & 3.2 & 3.6 \\
\hline Greece & 0.7 & 2.1 & 2.8 & 0.2 & 0.7 & 0.8 & 0.6 & 1.4 & 2.0 & 0.4 & 2.2 & 3.5 & 0.6 & 0.8 & 0.9 \\
\hline Ireland & 4.4 & 7.4 & 8.7 & 0.1 & 2.8 & 4.1 & 4.3 & 4.5 & 4.4 & 2.7 & 3.3 & & 3.6 & 4.4 & \\
\hline Netherlands & 2.2 & 3.1 & 3.4 & -1.1 & 0.9 & 1.7 & 3.3 & 2.1 & 1.6 & 3.6 & 3.4 & 3.5 & 2.3 & 1.6 & 1.2 \\
\hline New Zealand & 1.3 & 2.9 & 3.3 & -0.1 & 2.1 & 2.3 & 1.4 & 0.7 & 0.9 & 3.1 & 2.2 & 2.5 & 0.2 & 0.8 & 0.9 \\
\hline Norway & 1.4 & 2.5 & 2.9 & -0.5 & 0.2 & 1.0 & 1.9 & 2.2 & 1.8 & 2.7 & 2.1 & 2.9 & 1.2 & 1.7 & 1.3 \\
\hline Portugal & 3.7 & 2.1 & .. & 0.7 & -0.4 & .. & 3.0 & 2.5 & .. & .. & .. & 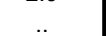 & .. & .. & \\
\hline Switzerland & 1.7 & 0.5 & .. & & 0.1 & 0.1 & .. & 0.3 & .. & .. & 2.7 & .. & .. & .. & .. \\
\hline Korea & 9.2 & 6.1 & 4.1 & 2.0 & 1.0 & 0.3 & 7.0 & 5.0 & 3.8 & .. & .. & .. & .. & & .. \\
\hline \multicolumn{16}{|c|}{ Weighted average: } \\
\hline EU15 $^{\prime}$ & 2.5 & 2.2 & 2.6 & -0.2 & 0.3 & 0.9 & 2.7 & 1.9 & 1.6 & 3.4 & 3.1 & 2.9 & 1.5 & 1.0 & 0.9 \\
\hline OECD24 $4^{8}$ & 3.1 & 2.7 & 3.0 & 0.9 & 1.0 & 1.3 & 2.1 & 1.7 & 1.7 & 3.7 & 3.1 & 3.1 & 1.3 & 1.1 & 1.1 \\
\hline \multicolumn{16}{|c|}{ Standard deviation: } \\
\hline EU15' & 0.84 & 1.40 & 1.77 & 0.64 & 0.85 & 1.09 & 0.93 & 0.84 & 0.89 & 1.09 & 1.01 & 0.96 & 0.77 & 1.07 & 0.82 \\
\hline $\mathrm{OECD} 24^{8}$ & 0.91 & 1.31 & 1.59 & 0.92 & 0.99 & 1.15 & 0.99 & 0.89 & 0.79 & 1.21 & 1.08 & 1.06 & 0.81 & 0.90 & 0.68 \\
\hline
\end{tabular}

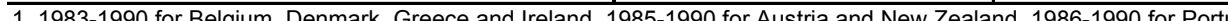

2. 1991-1996 for Switzerland, 1990-1997 for Austria, Belgium, New Zealand, 1990-1998 for Ireland, Korea and Netherlands, 1990-1999 for Denmark, Greece,Japan and United Kingdom.

3. 1996-1997 for Austria, Belgium, New Zealand, 1996-1998 for Ireland, Korea and Netherlands, 1996-1999 for Denmark, Greece,Japan and United Kingdom.

4. 1983-1990 for Belgium, Denmark, Greece and Ireland, 1985-1990 for Austria and New Zealand, 1987-1990 for United Kingdom.

5. 1991-1996 for Switzerland, 1990-1996 for Ireland and Sweden, 1990-1997 for Austria, Belgium, New Zealand and United Kingdom, 1990-1998 for Netherlands, 1990-1999 for Australia,

Denmark, France, Greece, Italy and Japan.

6. 1996-1997 for Austria, Belgium, New Zealand and United Kingdom, 1996-1998 for Netherlands, 1996-1999 for Australia, Denmark, France, Greece, Italy and Japan

7. Excluding Luxembourg.

8. Excluding Czech Republic, Hungary, Iceland, Korea, Luxembourg, Mexico, Poland, Slovak Republic and Turkey. 
Table 2. MFP regressions: selection of the baseline specification

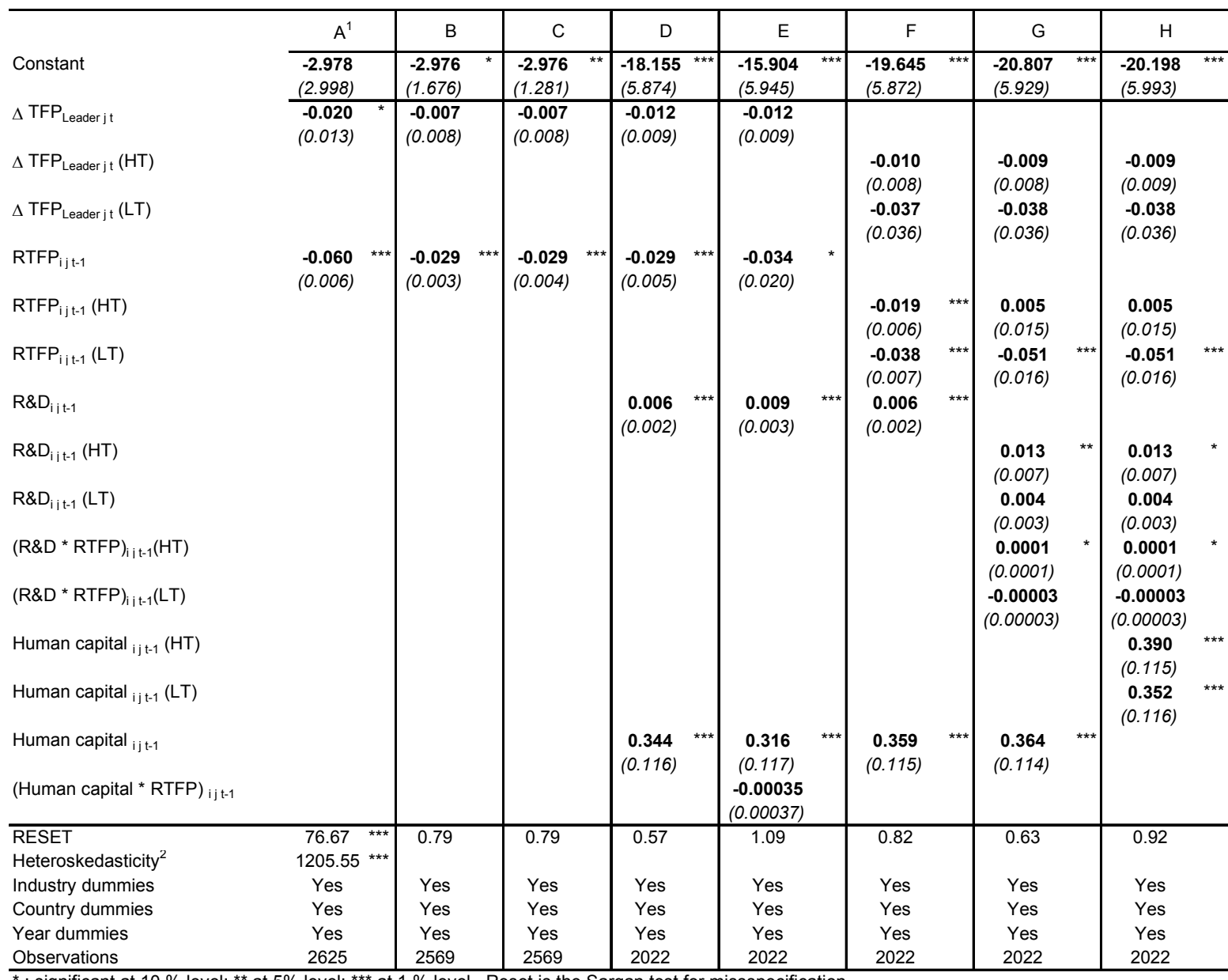

O : significant at $10 \%$ level; ${ }^{* *}$ at $5 \%$ level; ${ }^{* * *}$ at $1 \%$ level. Reset is the Sargan test for missspecification.

1. Full sample, no control for heteroskedasticity.

2. Cook Weisberg test of heteroskedasticity.

Robust standard errors (from eq.B) in parentheses.

Samples are adjusted for outliers from equation $\mathrm{C}$ onwards. See main text. 
Table 3. MFP regressions: the role of labour market institutions

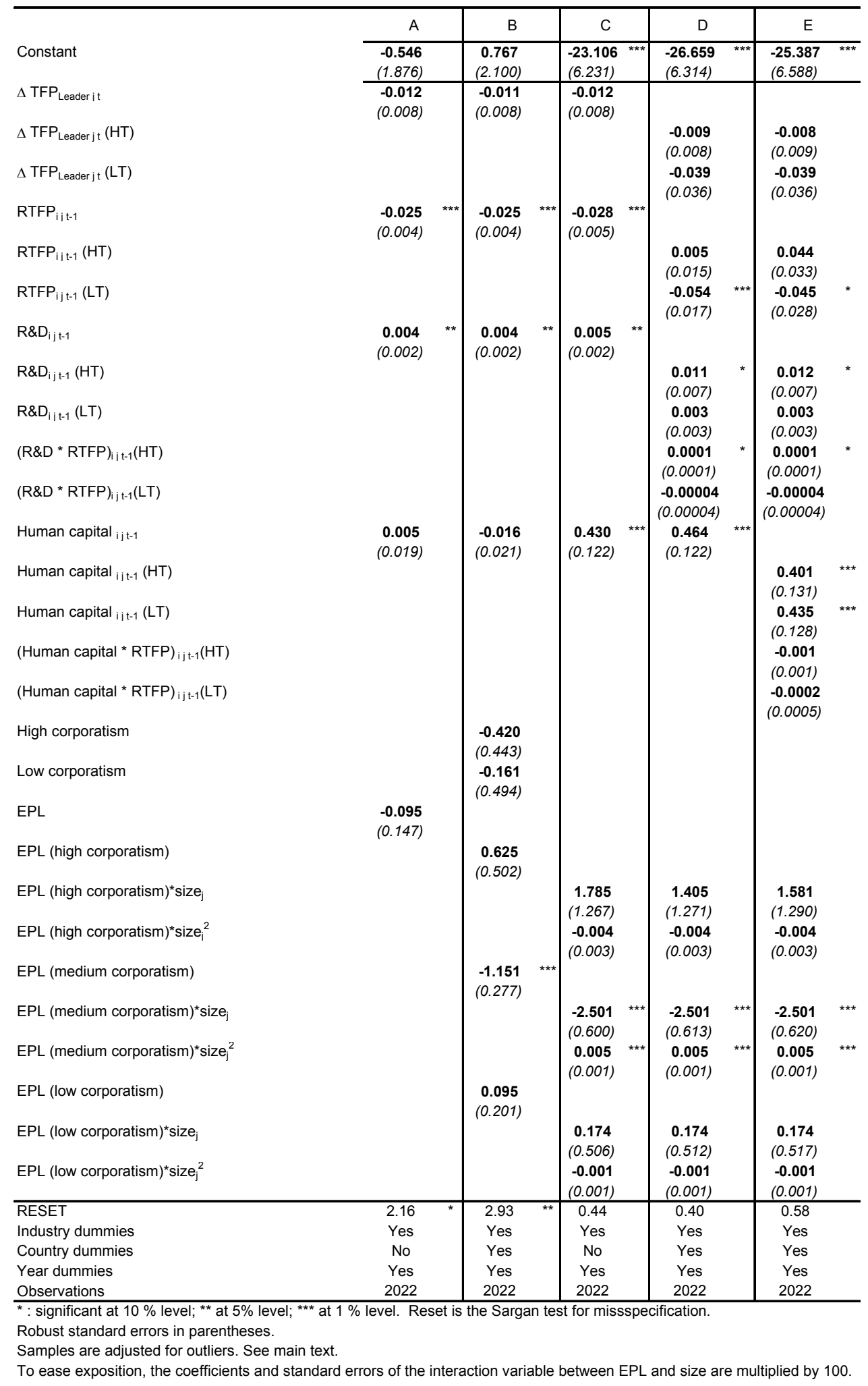


Chart 1. Labour productivity growth in manufacturing and its break down by technology groups, 1990-98 (average annual growth )

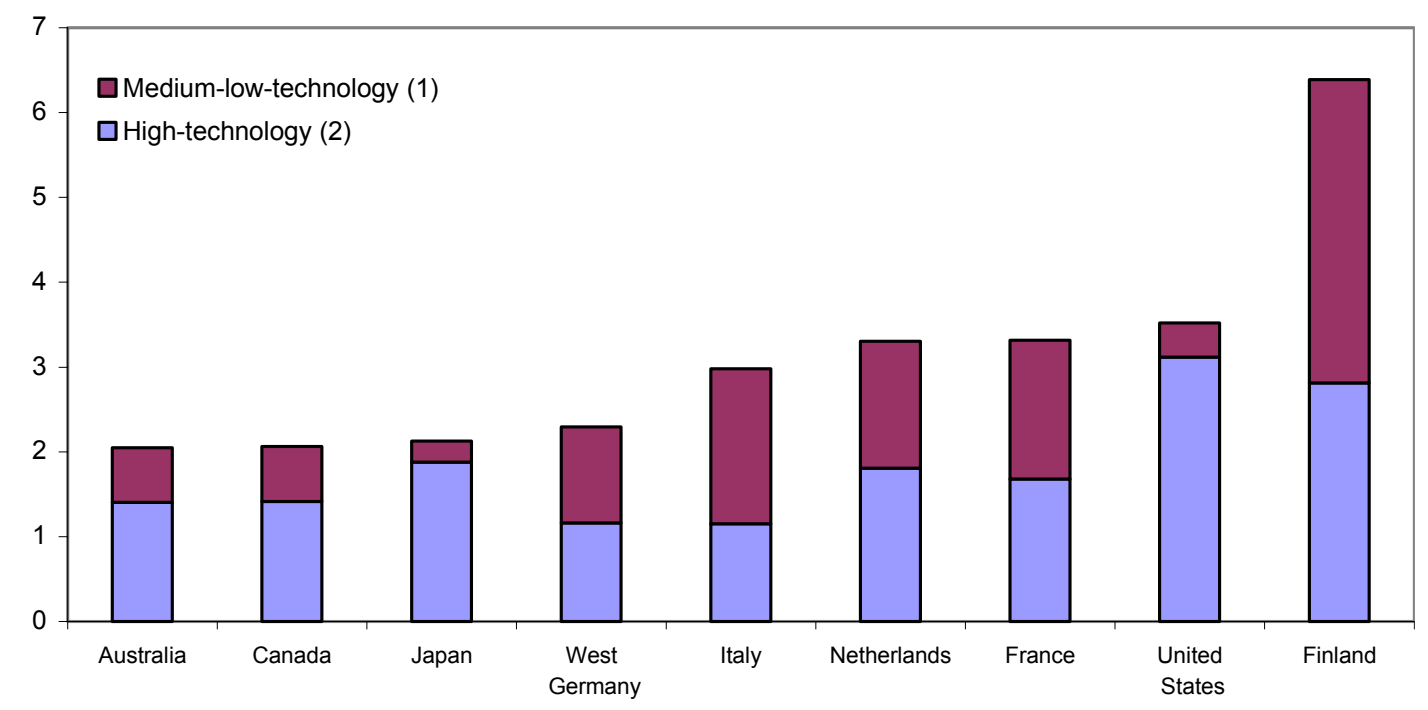

1. Coke, refined petroleum products and nuclear fuel, rubber and plastics products, other non-metallic mineral products, basic metals and fabricated metal products, bulding and repairing of ships and boats and manufacturing n.e.c, food products, beverages and tobacco, textiles, textiles products, leather and footwear, wood and products of wood and cork, pulp, paper, paper products, printing and publishing, furniture.

2. Pharmaceuticals, office, accounting and computing machinery, radio, television and communication equipment, aircraft and spacecraft, chemicals excluding pharmaceuticals, machinery and equipment, n.e.c, electrical machinery

and apparatus, n.e.c, medical, precision and optical instruments, motor vehicles, trailers and semi-trailers, railroad equipment and transport equipment n.e.c. 


\section{Chart 2. Industrial relations regimes, employment protection and the acceleration in MFP growth, 1980-2000}

Panel A: Acceleration in MFP growth and industrial relations regimes

Difference in average MFP growth rate between 1980-1990 and 1990-2000

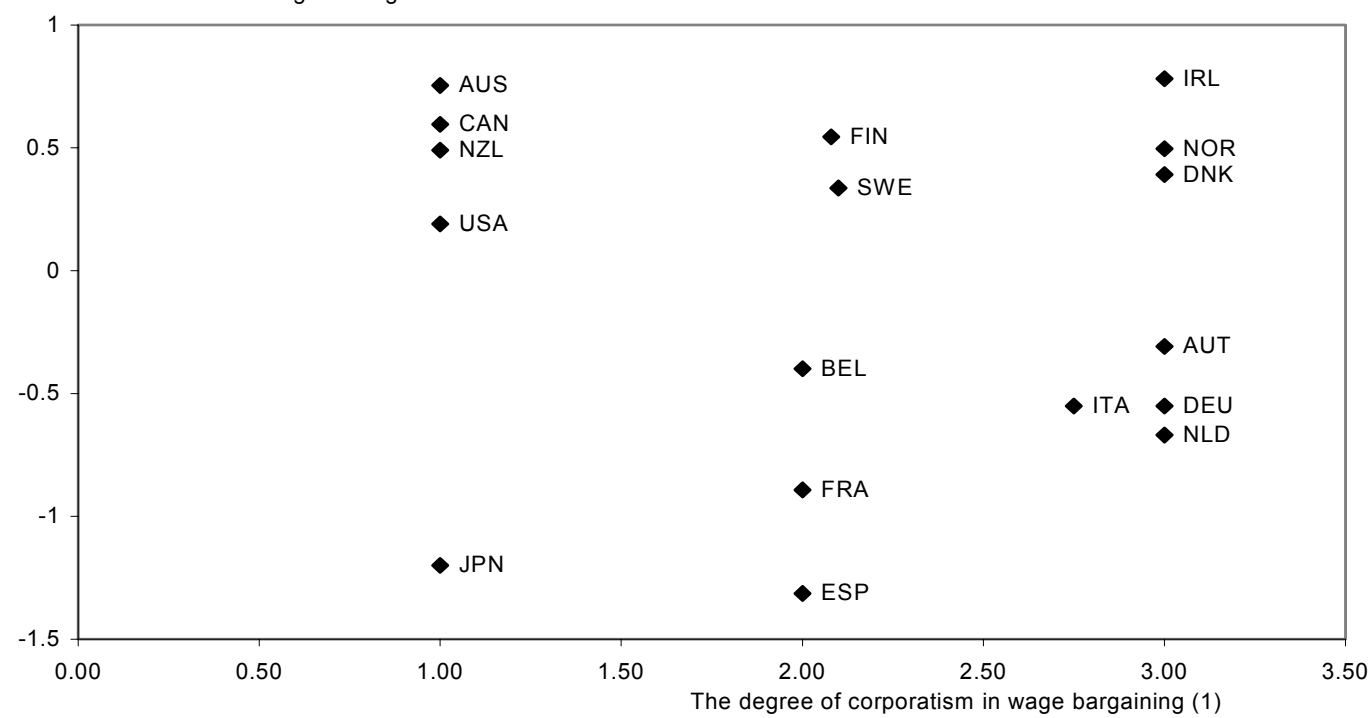

Panel B: Acceleration in MFP growth and employment protection legislation

Difference in average MFP growth rate between 1980-1990 and 1990-2000

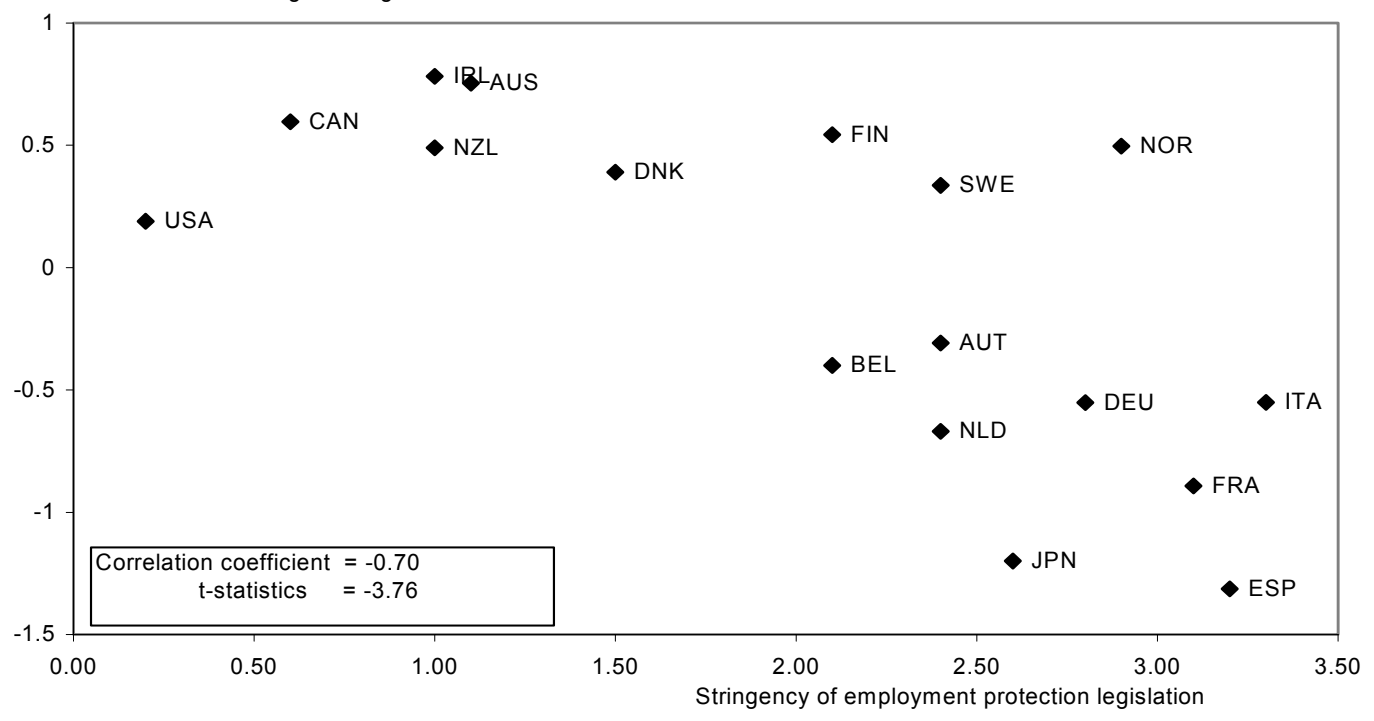

1. The indicator of corporatism combines two aspects: i) the level of bargaining: centralized, intermediate (at sector or regional), or decentralized (firm level); and ii) the degree of coordination amongst employers' associations. See main text for more 


\section{Appendix: Data sources}

\section{Source of the different data}

Data on hours worked are from ILO for the following countries: Australia, Austria, Finland, France, Norway, Portugal, Spain, Greece, Italy, Japan Netherlands and New Zealand. For manufacturing industries, we use the data for total manufacturing. For the sectors 41 and 42 (see Table below), we have data for: Australia, Austria, Finland, France, Portugal, Spain, Greece, Italy and Netherlands. For Norway, Japan and New Zealand we use data of industry 40. For sectors 44, 45, we use data of sector 43 for all countries. For sectors 47 and 51, we have the data for: Australia, Austria, Finland, France, Portugal, Spain, Greece, Italy and Netherlands. We use data of sector 46 for Norway and New Zealand. For the United States, we use the data from the BLS. Data are from CRONOS for the following countries: Belgium, Denmark and Germany. For Canada, we use data from the National Statistics Office.

Wage data are country-industry specific observations. They are from the OECD-DELSA database on employment. The primary source of the data is the European Structure of Earnings Survey (Eurostat) for EU countries, OECD calculations on the microdata file of the outgoing rotation group of the Current Population Survey for the US, and Structure of Earnings Surveys or Labour Force Surveys for the other countries. The observation is 1998 for non-EU countries, 1994 for France, 1996 for Sweden, 1995 for other EU countries. Data on wages for Portugal, Netherlands, Finland, Norway, Germany, Australia and Japan are not included. In order not to drop these countries when using skill data, we make the following assumption: we use the relative wages of a neighbour country when available, or the US data otherwise. For Portugal, we use Spain, for Netherlands we use Belgium, for Finland and Norway we use Sweden; for Germany we use Austria; for Canada, Australia and Japan we use the US.

Data on the skill composition of employment also have a country, industry and time dimension. ${ }^{22}$ These data are from several sources: (1) the OECD-DELSA data described above, (2) the skill data in OECD STI Working Paper No. 1998/4; and (3) ILO data on aggregate employment for the four skill categories. Data from (2) typically have country, industry and time dimension, ${ }^{23}$ while those from (3) are panel data at the country level. Our dataset was constructed in the following way: we used (2) as the baseline source; then we complemented these data using (1) and (3) for the following countries: Austria, Belgium, Canada, Denmark, Greece, Netherlands, Norway, Portugal, Spain and Sweden. The procedure was the following: when the industry breakdown was available in (1), we used this single observation to compute, for each skill category, the industry wage relative to the country (weighted) average wage, and used this differential to construct time series from the aggregate source (3) data.

We used industry-specific PPPs to convert volume output into a comparable currency (se Sørensen, 2001, for a critics of the use of nation-wide GDP PPPs for the comparison of

22 Except for Canada for which we do not have the manufacturing detail and Norway data do not have the sectoral decomposition.

23 Depending on the country considered, the number of (non consecutive) observation varies between 2 and 5. We use a linear extrapolation between the two extreme points to obtain a panel dataset. 
productivity levels, as in Bernard and Jones, 1986a,b). The starting point of these calculations was the PPPs for detailed expenditure headings from the United Nations International Comparisons Project (ICP). These detailed PPPs were mapped into the STAN classification of industries by assigning each basic expenditure heading bought by consumers, firms or the government to its industry of origin. When the basic heading includes products produced in more than one industry, the same price was assigned to all the industries concerned. Within each industry, proxies of the product prices were obtained aggregating the basic headings with the corresponding expenditure shares. However, as suggested by Harrigan (1997), there are a number of problems in using expenditure PPPs for industry productivity comparison. In particular the presence of distribution and transportation margins, indirect taxes and the inclusion/exclusion of the prices of imported/exported goods all tend to create a gap between expenditure prices and production prices. While available data did not allow accounting for distribution and transportation margins, corrections for both indirect taxes and international trade were made. In particular, in the abovementioned Secretariat work, the correction for indirect taxes was made using the following formula :

$$
P P P_{i, j}^{a d j I}=\frac{1+t_{i, j}}{1+t_{U S, j}} \cdot P P P_{i, j}
$$

where $t_{i, j}$ is the indirect tax rate of country $i$ in industry $j$.

The impact of trade on the differential between expenditure and production prices is larger the more the sectoral expenditure price differs from the exchange rate. Since imports and exports have opposite effects on this differential, only the net trade position is relevant. The following adjustment was made to PPPs:

$$
P P P_{i, j}^{a d j I I}=P P P_{i, j}^{a d j I}+\frac{X_{i, j}-M_{i, j}}{Y_{i, j}} \cdot\left(e-P P P_{i, j}^{a d j I}\right)
$$

where $X$ stands for industry exports, $M$ for industry imports, $Y$ for industry output, and $e$ for the exchange rate.

As a final test of robustness, the whole analysis (e.g. for the different measures of labor input) was repeated by using aggregate PPPs for GDP from STD, National Accounts of OECD Countries - Main Aggregates. Vol. I - 2002 Edition.

In a number of instances, the industry time series of the capital stock was not readily available in the original databases. If data on gross fixed capital formation were available, we used the perpetual inventory method to construct a proxy for the capital stock following the OECD ISDB User Guide:

$$
G C S_{t}=\sum_{j=0}^{2 A S L-5} I N V_{t-j} \cdot g_{t-j}
$$

where: GCS is the gross capital stock at constant prices, $I N V$ is gross fixed capital formation at constant prices; $g$ is the survival coefficient; $j$ is the vintage of investment; $A S L$ is the average service life. The survival coefficient is given by: $g=1$ if $j<5$ and $g=1-1 / 2(A S L-5)$ if $j>4$ and $j-$ $1<2$ ASL-5 (depreciation starts at date t-5). Average services lives (ASL) are from ISDB98 methods used by OECD countries to measure stocks of fixed capital, OECD, Paris (1993). 
The formula above implies the following recursive relation of the stock of capital for adjacent dates:

$$
G C S_{t}=G C S_{t-1}+I N V_{t}-\frac{1}{2(A S L-5)} \sum_{j=5}^{2 A S L-5} I N V_{t-j}
$$

Gross capital stocks are calculated from this formula.

The indicator of the stringency of Employment Protection Legislation (EPL) is from Nicoletti, Scarpetta and Boylaud. 1999. Regulations for regular contracts include: i) procedural inconveniences that employers face when trying to dismiss a worker; ii) advance notice of the dismissal and severance payments; and iii) prevailing standards of, and penalties for, "unfair" dismissals. Indicators of the stringency of EPL for temporary contracts include: i) the "objective" reasons under which they can be offered; ii) the maximum number of successive renewals; iii) and the maximum cumulated duration of the contract.

The summary indicator of the bargaining system combines two aspects: the level of bargaining, being centralised, intermediate (at sector or regional), or decentralised (firm level); and the degree of coordination amongst employers. This combined variable allows considering cases where co-operation between employers and unions in an industry bargaining setting (e.g., Germany and Austria and, more recently, Italy, Ireland, the Netherlands with the income policy agreements) may be an alternative, or functionally equivalent, to centralised systems, thereby mimicking their outcomes. The distribution of countries according to the different aspects of collective bargaining and changes over time is presented in Elmeskov, Martin and Scarpetta (1998).

Finally, data on average firm size for different manufacturing industries are from the OECD firm-level database that includes data for ten OECD countries based on harmonized definitions (see Bartelsman et al. 2003). 
Appendix Table Industries considered in the empirical analysis by technology groups

\begin{tabular}{|c|c|c|}
\hline Description & ISIC Rev.3 & Technology group \\
\hline 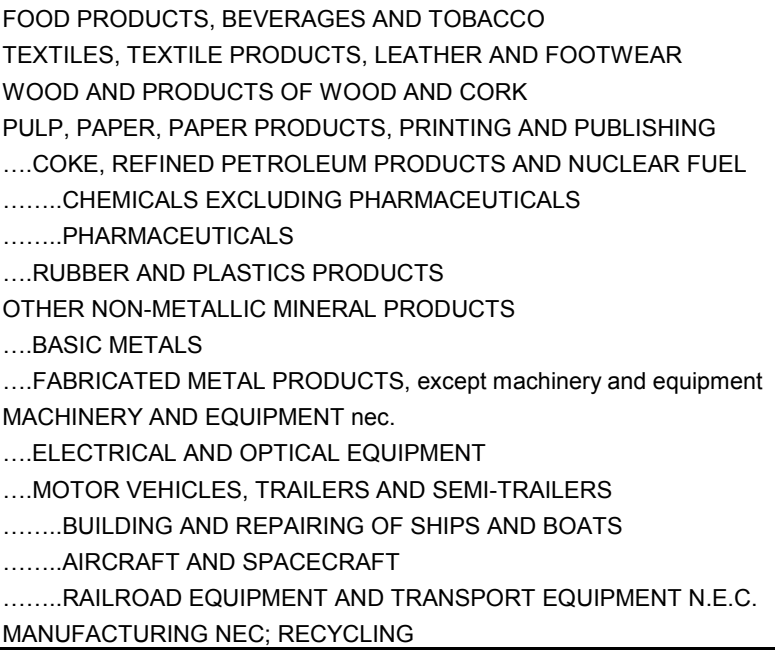 & \begin{tabular}{r||}
$15-16$ \\
$17-19$ \\
20 \\
$21-22$ \\
23 \\
$24 \mathrm{ex} 2423$ \\
2423 \\
25 \\
26 \\
27 \\
28 \\
29 \\
$30-33$ \\
34 \\
351 \\
353 \\
$352+359$ \\
$36+37$ \\
\end{tabular} & \begin{tabular}{|l} 
Low Tech \\
Low Tech \\
Low Tech \\
Low Tech \\
Low Tech \\
High Tech \\
High Tech \\
Low Tech \\
Low Tech \\
Low Tech \\
Low TEch \\
High Tech \\
High Tech \\
High Tech \\
Low Tech \\
High Tech \\
High Tech \\
High Tech
\end{tabular} \\
\hline
\end{tabular}


Appendix Table Relative MFP levels and the technology leaders, 1984, 1997

\begin{tabular}{|c|c|c|c|c|c|c|c|c|c|}
\hline & \multirow[t]{2}{*}{ rank } & \multirow[t]{2}{*}{1984} & \multirow[t]{2}{*}{1997} & \multicolumn{2}{|c|}{$\begin{array}{c}\text { Basic statistics }{ }^{1} \\
(1997)\end{array}$} & \multirow[t]{2}{*}{1984} & \multirow[t]{2}{*}{1997} & \multicolumn{2}{|c|}{$\begin{array}{c}\text { Basic statistics }{ }^{1} \\
(1997)\end{array}$} \\
\hline & & & & Mean & S. D. & & & Mean & S. D. \\
\hline \multirow[t]{3}{*}{ Food products, beverages and tobacco } & $1^{\text {st }}$ & USA & CAN & 0.69 & 0.17 & USA & CAN & 0.69 & 0.14 \\
\hline & $2^{d}$ & JPN & USA & & & JPN & USA & & \\
\hline & $3^{\mathrm{a}}$ & CAN & JPN & & & CAN & JPN & & \\
\hline \multirow[t]{3}{*}{ Textiles, textile products, leather and footwear } & $1^{\text {st }}$ & FRA & CAN & 0.71 & 0.15 & FRA & CAN & 0.75 & 0.15 \\
\hline & $2^{a}$ & CAN & FRA & & & CAN & FRA & & \\
\hline & $3^{\mathrm{a}}$ & AUS & USA & & & AUT & ITA & & \\
\hline \multirow[t]{3}{*}{ Wood and products of wood and cork } & $1^{\text {st }}$ & USA & USA & 0.60 & 0.23 & CAN & USA & 0.59 & 0.21 \\
\hline & $2^{a}$ & CAN & FIN & & & USA & FIN & & \\
\hline & $3^{a}$ & GRC & ITA & & & GRC & NOR & & \\
\hline \multirow{3}{*}{ Pulp paper, paper products, printing and publishing } & $1^{\text {st }}$ & CAN & CAN & 0.70 & 0.15 & CAN & FRA & 0.74 & 0.13 \\
\hline & $2^{a}$ & USA & FRA & & & FRA & CAN & & \\
\hline & $3^{a}$ & FRA & FIN & & & USA & ITA & & \\
\hline \multirow[t]{3}{*}{ Coke, refined petroleum products and nuclear fuel } & $1^{\text {st }}$ & ITA & ITA & 0.38 & 0.24 & ITA & ITA & 0.38 & 0.24 \\
\hline & $2^{\mathrm{a}}$ & FRA & USA & & & FRA & FIN & & \\
\hline & $3^{\mathrm{a}}$ & USA & FIN & & & KOR & USA & & \\
\hline \multirow[t]{3}{*}{ Chemicals excluding pharmaceuticals } & $1^{\text {st }}$ & FIN & FIN & 0.50 & 0.26 & FIN & FIN & 0.50 & 0.26 \\
\hline & $2^{\mathrm{a}}$ & BEL & FRA & & & $\mathrm{BEL}$ & FRA & & \\
\hline & $3^{\mathrm{a}}$ & CAN & CAN & & & GER & CAN & & \\
\hline \multirow[t]{3}{*}{ Pharmaceuticals } & $1^{\text {st }}$ & JPN & CAN & 0.60 & 0.39 & JPN & CAN & 0.65 & 0.40 \\
\hline & $2^{a}$ & USA & NOR & & & USA & NOR & & \\
\hline & $3^{\mathrm{a}}$ & CAN & GBR & & & NOR & GER & & \\
\hline \multirow[t]{3}{*}{ Rubber and plastics products } & $1^{\text {st }}$ & AUT & USA & 0.64 & 0.14 & AUT & ITA & 0.69 & 0.13 \\
\hline & $2^{\mathrm{a}}$ & ESP & ITA & & & DNK & FIN & & \\
\hline & $3^{\mathrm{d}}$ & NLD & FIN & & & ESP & USA & & \\
\hline Other non-metallic mineral products & $1^{\text {st }}$ & CAN & CAN & 0.71 & 0.15 & CAN & CAN & 0.76 & 0.15 \\
\hline & $2^{\mathrm{a}}$ & BEL & FRA & & & AUT & FRA & & \\
\hline & $3^{\mathrm{a}}$ & GER & USA & & & BEL & USA & & \\
\hline Basic metals & $\overline{1^{\text {st }}}$ & JPN & JPN & 0.71 & 0.18 & NLD & FIN & 0.72 & 0.17 \\
\hline & $2^{\mathrm{a}}$ & NLD & FIN & & & DNK & JPN & & \\
\hline & $3^{\mathrm{a}}$ & USA & CAN & & & JPN & NOR & & \\
\hline Fabricated metal products except machinery and equipment & $1^{\text {st }}$ & CAN & USA & 0.71 & 0.17 & CAN & USA & 0.76 & 0.17 \\
\hline & $2^{a}$ & USA & FIN & & & BEL & FIN & & \\
\hline & $3^{\mathrm{a}}$ & $\mathrm{BEL}$ & JPN & & & GER & JPN & & \\
\hline Machinery and equipment n.e.c. & $1^{\text {st }}$ & CAN & FRA & 0.70 & 0.20 & CAN & FRA & 0.77 & 0.12 \\
\hline & $2^{\mathrm{a}}$ & GER & FIN & & & GER & FIN & & \\
\hline & $3^{\mathrm{d}}$ & JPN & ITA & & & DNK & ITA & & \\
\hline Electrical and optical equipment & $1^{\text {st }}$ & AUS & FIN & 0.62 & 0.25 & AUS & FIN & 0.70 & 0.21 \\
\hline & $2^{a}$ & JPN & JPN & & & DNK & JPN & & \\
\hline & $3^{\mathrm{a}}$ & ITA & FRA & & & JPN & FRA & & \\
\hline Motor vehicles trailers and semi-trailers & $1^{\text {st }}$ & USA & USA & 0.64 & 0.21 & USA & USA & 0.82 & 0.13 \\
\hline & $2^{a}$ & GRC & FRA & & & GRC & FRA & & \\
\hline & $3^{a}$ & CAN & FIN & & & CAN & FIN & & \\
\hline Building and repairing of ships and boats & $1^{\text {st }}$ & FRA & USA & 0.63 & 0.24 & FRA & CAN & 0.76 & 0.21 \\
\hline & $2^{a}$ & USA & JPN & & & USA & GER & & \\
\hline & $3^{\mathrm{a}}$ & JPN & CAN & & & ITA & NOR & & \\
\hline Aircraft and spacecraft & $1^{\text {st }}$ & FRA & CAN & 0.47 & 0.31 & FRA & CAN & 0.47 & 0.30 \\
\hline & $2^{\mathrm{a}}$ & CAN & NLD & & & CAN & GER & & \\
\hline & $3^{a}$ & NLD & GER & & & GER & NLD & & \\
\hline Railroad equipment and transport equipment n.e.c. & $1^{\text {st }}$ & CAN & CAN & 0.47 & 0.28 & ITA & CAN & 0.56 & 0.24 \\
\hline & $2^{a}$ & ITA & FIN & & & CAN & FIN & & \\
\hline & $3^{a}$ & FRA & JPN & & & FRA & GBR & & \\
\hline Manufacturing n.e.c; recycling & $1^{\text {st }}$ & CAN & USA & 0.84 & 0.17 & CAN & FRA & 0.83 & 0.15 \\
\hline & $2^{a}$ & USA & FRA & & & USA & USA & & \\
\hline & $3^{\mathrm{d}}$ & FIN & FIN & & & FIN & FIN & & \\
\hline
\end{tabular}

Note: Data for Germany refer to western Germany.

1. If 1997 data were not available, basic statistics refer to the most recent year with sufficiently large country coverage. 